\title{
A Review of Black Grass Bug Resistance in Forage Grasses
}

\author{
W.F. CAMPBELL, B.A. HAWS, K.H. ASAY, AND J.D. HANSEN
}

\begin{abstract}
Large ares (6 million ha) of the United States and Canada, classified as range, have an enormous impact on the economy and environment through grass production. Production is often drastically reduced by infestations of grass-feeding insects. Although the literature is voluminous with references dealing with responses of agronomic crop plants to attacks by these insects, little research has been conducted on range grasses. The black grass bugs, Labops spp and Irbisia spp (Hemiptera: Miridae), are economically important on rangeland of the Intermountain West. The recognized mechanisms of plant resistance to insects are nonpreference, tolerance, and antibiosis. Trichome length and density within species of wheatgrasses (Agropyron sp) are negatively correlated with feeding behavior of the early instars of $L$ abops hesperius Uhler, but not with older instars or adults. Certain species of wheatgrasses show varying degrees of tolerance to feeding by $\boldsymbol{L}$. hesperius. Approximately 3,000 chemical compounds afford plants some protection against insects. During their long co-evolution with plants, however, insects overcame the toxic effects of many chemical compounds. Essentially no plant breeding has been done to develop range grass cultivars that are resistant to black grass bugs. Nevertheless, the opportunities are as great as the need that must be met if western rangelands are to satisfy multiple demands the future is likely to impose on them.
\end{abstract}

Seeding vast areas (more than 6 million ha) in the western United States and Canada (Dewey and Asay 1975, Rogler and Lorenz 1983) with adapted species of wheatgrasses (Agropyron sp.) has aided immeasurably in supplementing native vegetation and lengthening the grazing season. As Hagen et al. (1971) have poignantly reaffirmed, very little is known about range insects and their association with plants. So it is not surprising that the wheatgrass monoculture has also encouraged the increase in populations of destructive insects. The most important of these are the black grass bugs (Hemiptera:Miridae): Labops hesperius Uhler, Irbisia brachycera (Uhler), and Irbisia pacifica (Uhler). Knowlton (1967) reported that these species damaged about 80,000 ha of Utah rangeland in 1966. Other areas severely affected by black grass bugs are in Montana (Mills 1939), Nevada (Haws et al. 1982), New Mexico (Dickerson 1978), Oregon (Todd and Kamm 1974), and Wyoming (Denning 1948). Black grass bugs feed on both introduced and native grasses (Bohning and Currier 1967, Knowlton 1945, Mills 1939, Slater 1954, Todd and Kamm 1974), yet typically prefer monocultures of wheatgrass (Higgins et al. 1977, Jensen 1971).

Chemical control of black grass bugs has been attempted as has been done with various species of grasshoppers (Orthoptera:Acrididae), the Mormon cricket, (Anabrus simplex Haldeman) (Orthopthera:Tettigoniidae), and the range caterpillar, (Hemileuca oliviae Cockerell) (Lepidoptera:Saturuiidae). Unfortunately, continuous chemical application on western range is not economically feasible

Authors are professors, crop physiology and biology/entomology, Utah State University; research geneticist and research entomologist, USDA-ARS, Logan, Utah 84322.

This article is a contribution of the Plant Science and Biology Department and the USDA-ARS, Utah State University, Logan 84322. Utah Agricultural Experimen Station Journal Paper No. 2834.

Manuscript received April 22, 1982. because of the relatively high application costs on the large areas of low value land.

However, a practical method of controlling range pests is to reseed with insect resistant grasses. This has already been initiated with other grass feeding insects. Differences in feeding preferences for range grasses have been studied with 60 species of short-horned grasshoppers (Orthoptera:Acrididae) (Mulkern et al. 1969), a range thrip, (Chirothrips falsus Priesner) (Thysanoptera:Thripidae) (Watts 1965), the chinch bug, [Blissus leucopterus leucopterus (Say)] (Hemiptera:Lygaeidae) (Hayes and Johnston 1925), an aphid, [Rhopalosiphum padi (L.)], the corn leaf aphid, [Rhopalosiphum maidis (Fitch)], the English grain aphid, [Macrosiphum avenae (Fabricius)], and the greenbug, [Schizaphis graminum (Rondani)] (Homoptera:Aphididae) (Jackson et al, 1981, Kieckhefer and Stoner 1978). Feeding tolerance of cultivars of Kentucky bluegrass (Poa pratensis L.) has also been evaluated for the hairy chinch bug (Blissus leucopterus hirtus Montandon) (Baker et al. 1981). Antibiosis has been observed in range grasses to 4 species of aphids (Stoner and Kieckhefer 1979) and in accessions of St. Augustinegrass [Stenotaphrum secundatum (Walt.) Kuntze], to the southern chinch bug (Blissus insularis Barber) (Reinert and Dudeck 1974).

The first extensive work on plant resistance to insects was published by Painter in 1951. He included a comprehensive review of the literature to that time and the principles of plant resistance to insects. Subsequent review papers were published by Painter (1958), Beck (1965), Maxwell et al. (1972), Gallun et al. (1975), and Farrell (1977). Several other workers have reported on various aspects of plant resistance to insects (Jermy 1976, Hedin 1983, Maxwell and Jennings 1980, Rosenthal and Janzen 1979, and Russell 1978). However, none of these studies have dealt with the biology or habits of phytophagous insects on range grasses. Only very limited research now being done on morphological and biochemical differences among breeding lines of range grass species or interspecific hybrids can be correlated with the feeding behavior of black grass bugs (Brewer and Campbell 1977; Brewer et al. 1979; Haws et al. 1978, 1982; Ling et al. 1982a, b; Windig et al. 1983). In this review, we attempted to summarize information dealing with plant resistance, morphological and biochemical traits of range grasses associated with their resistance to black grass bugs. Because of a dearth of information on responses of range grasses to insect attack, data from other plants are cited as illustrations.

\section{Plant Resistance to Insect Attack}

Plant resistance is the heritable ability of the host plant to reduce infestation and/or damage by insect (Gallun and Khush 1980). The existence of plant resistance can be credited to a long continuing co-evolutionary process between plant-eating insects and their hosts. According to Ehrlich and Raven (1964), the plant-herbivore interface may be the major zone of interaction responsible for generating terrestrial organic diversity. From the standpoint of natural selection in evolution, host plant resistance is a preadaptive characteristic of plants. Plants co-evolving with insects intrinsically possessed or have developed means of surviving attack by insects (Waiss et al. 1977).

Resistant plant cultivars can form the foundation of an inte- 
grated system of pest control. On rangeland with a limited cash value per unit area, the use of resistant cultivars may, in fact, be the most practical control method. The advantages of having resistant cultivars are several: (1) Pest control through resistance is cumulative and economical. (2) Resistance to one pest species may also provide resistance to several others. (3) Resistant cultivars reduce the vigor and number of insect pests, making them more vulnerable to natural enemies and other control methods. Even a low level of resistance may, in combination with natural enemies, effectively control a pest when either method would be inadequate when used alone. (4) Use of resistant cultivars avoids putting chemical residues into the food chain or the environment and is a non-energy consuming pest control mechanism. (5) Incorporation of resistant cultivars in a control program conserves natural enemies and is in harmony with environmental quality considerations (Adkisson and Dyck 1980, Hedin 1983, Horber 1972, Maxwell and Jennings 1980).

Painter (1951) and later Gallun (1972) listed 3 mechanisms or types of resistance: (1) preference or nonpreference-to denote the plant characters that lead an insect to or away from a particular plant or variety for oviposition, food, shelter, or for combinations of the 3 ; (2) tolerance-the plant is able to grow, reproduce, and repair injury in spite of supporting a population that would damage a susceptible host; and (3) antibiosis-comprises the adverse influence of plants on growth, survival, or reproduction of their insect pests by means of chemical or morphological factors. According to Beck's (1965) definition of a plant with resistance, it is able to reduce the successful utilization of itself as a host by an insect. This definition omits tolerance as a type of resistance. Beck and Maxwell (1976) redefined the types of resistance as resistance to: oviposition, feeding, development, and survival.

Types of resistance are frequently interrelated (Beck 1965). Preference, tolerance, and antibiosis were all shown to affect resistance of pearl millet [Pennisetum typhoides (Burm.) Stapf \& C.E. Hubb.] to the fall armyworm, [Spodoptera frugiperda (J.E. Smith] (Lepidoptera:Noctuidae) (Leuck 1972). Wilson et al. (1978) studied resistance in 4 oat (Avena sativa $\mathrm{L}$.) lines of 2 biotypes of the greenbug, [S. graminum (Rondani)]. They reported various interactions including 2 oat lines showing nonpreference, tolerance, and antibiosis in both biotypes of the greenbug. Hewitt (1980) rated tolerance in 10 species of wheatgrass to feeding by $L$. hesperius. He found tall wheatgrass, [Elytrigia elongata (Host) Nevski (Dewey $1983 \mathrm{a}, \mathrm{b})$ ], slender wheatgrass, [Elymus trachycaulus (Link) Gould ex Shinners], and intermediate wheatgrass, [Elytrigia intermedia (Host) Nevski], to be somewhat tolerant to black grass bug feeding.

As part of the USDA-ARS grass breeding program at Utah State University, a breeding nursery consisting of 500 accessions representing 60 species and interspecific hybrids was established on a surface mine near Decker, Mont. In 1980, several plots became infested with larvae of the bluegrass billbug, (Sphenophorus parvulus Gyllenhal) (Coleoptera:Curculionidae). Significant differences in susceptibility were observed among and within species, with slender wheatgrass and its related species being the most heavily damaged. Breeding lines of crested wheatgrass, $[A$. desertorum (Fisch. ex Link) Schult.], western wheatgrass, [Pascopyrum smithii (Rydb.) Löve](Dewey 1983a, b), and interspecific hybrids were not damaged, suggesting that selection for resistance to this devastating insect would be possible (Asay et al. 1983). Likewise, in Kentucky bluegrass cultivar trials in Nebraska, Kindler and Kinbacher (1975) and Lindgren et al. (1981) demonstrated genetic differences to an infestation of $S$. parvulus. While all cultivars showed some visual injury to the bluegrass billbug, 'South Dakota Certified', 'Delta', 'Park', 'Nu Dwarf', 'Merion', and 'Pennstar' exhibited significantly lower infestations than other cultivars tested, suggesting the potential for breeding or selecting for resistance in Kentucky bluegrass.

Improving resistance to plant pests (primarily insects and diseases) is a major objective of most forage breeding programs. Substantial progress has been made in many crops such as small grains, tuber and root crops, fiber crops, ornamentals, forage legumes, and forage grasses. Although heritable genetic variation in mechanisms that condition resistance to insects apparently exists in range grasses, little breeding work has been done to incorporate these characters into improved cultivars.

For practical reasons, plant resistance to insects is generally considered as biochemical or morphological in nature. Morphological (physical) resistance factors are, however, expressions of genetically regulated biochemical processs (Norris and Kogan 1980).

\section{Plant Physical Properties in Relation to Insect Resistence}

Differences in damage and the response of plant cultivars to insect attack have been on record for almost 200 years. The wheat (Triticum aestivum L.) cultivar 'Underhill' was reported as resistant to the Hessian fly, [Mayetiola destructor (Say)], (Diptera:Cecidomyiidae) by Haven in 1792 (Ortman and Peters 1980). Since then, major efforts have been made to exploit those differences and to develop crops that are resistant to their primary pests (Beck 1965 , Gallun et al. 1973, 1975). Resistance may result from physical properties of the plant, such as pubescence, thickened epidermis, a fibrous cuticle, a spiney surface, presence or absence of small cavities or crevices on the surface, and hardness of the plant tissue. Color and shape of plants also indirectly affect host selection behavior of phytophagous insects and have been associated with some resistance (Norris and Kogan 1980). A search of the literature, however, failed to reveal any evidence that these traits were associated with insect resistance in range grases.

Trichomes occur as hair-like (pubescence) appendages on the epidermis of aerial tissues of plants and vary widely in structure, function, and distribution over plant parts (Cutter 1976, Uphof 1962). These structures have been used widely for taxonomic classification, and they are effective defense mechanisms against phytophagous insects (McCollock and Yuasa 1917, Levin 1973).

Ling et al. (1982a) hypothesized that trichome length and density on the leaves of selected range grasses affect the feeding behavior of $L$. hesperius and impair bug movement. Thirty-four cultivars and synthetics of range grasses, representing the general Agropyron, Bromus, Dactylis, Elymus, Elytrigia, Leymus, Phalaris and Poa were exposed to $L$. hesperius. The hypothesis was acceptable within the genus Agropyron and instars II and III, but it was rejected with other grass genera or adult Labops. The bugs preferred intermediate wheatgrass, slender wheatgrass, and Kentucky bluegrass over crested wheatgrass [Agropyron desertorum (Fish ex Link) Schult.], reed canarygrass (Phalaris arundinaceae L.), or orchard grass (Dactylis glomerata L.). Grasses of the other genera were intermediate in their resistance to the $L$. hesperius bugs. Interestingly, the leaf surfaces of the Bromus, Dactylis, and Phalaris grasses were relatively free of trichomes, yet, plants of these genera were rarely damaged by Labops of any growth stages. These data suggest that the feeding insects' preferences were based on chemcial constituents.

\section{Plant Chemical Properties in Relation to Insect Resistance}

Stohl suggested in the late 1800 's that some of the chemical properties of plants may have evolved for protection against attack by herbivorous animals (Rosenthal and Janzen 1979). Chemical properties and insect/plant interrelationships have been extensively reviewed (Beck and Reese 1976, Chapman 1974, Hedin et al. 1974, Kogan 1978, Maxwell and Jennings 1980, Mittler and Sutherland 1969, Ryan 1973, Ryan and Green 1974, Schoonhoven 1972, Slama 1969, White 1976).

Categorized as attractants and repellents, the chemical properties might be further described as having nutritional, antinutritional, hormonal and generation of alternation action. As the name implies, repellents repel the insects and inhibit feeding. For example, some plants contain alkaloids that repel insects such as aphids. Other plant species contain saponins, alkaloids, and phenolic and cyanogenic glucosides that may have some allelochemic effect on the insects (Benson et al. 1975, Gilbert and Raven 1975, 
Schoonhoven 1972, Schoonhoven and Derksen-Koppers 1976, Tingey et al. 1978). Trichomes may complement the chemical defense of a plant with glands that exude terpenes, phenolics, alkaloids or other substances that are olfactorial or gustatorial repellants (Thurston 1970, Thurston et al. 1966). In essence, glandular trichomes afford an outer line of chemical defense by advertising the presence of noxious compounds.

Fraenkel $(1959,1969)$ pointed out that insect host attraction and eating behavior were largely controlled by compounds in the plant that had no known metabolic function. He suggested that the significance of these "secondary compounds" was in their repellent properties to insects and other herbivores. Since these early papers, knowledge of plant chemistry and secondary compounds has mushroomed. Swain (1977) reported that, of over 10,000 known secondary compounds from plants, more than 3,000 afford plants some protection against insects. The function of other secondary compounds is as yet undetermined. Because of the long and continued co-evolution of insects and their host-plants, many secondary compounds in plants have become ineffective in deterring insects, while research shows that some of these heretofore deterrent compounds have become feeding stimulants and attractants (Levin 1973). Several recent volumes give detailed accounts of plant secondary compounds and their role in resistance to insects (Harborne 1982, Hedin 1983, Jermy 1976, Maxwell and Jennings 1980, Rosenthal and Janzen 1979, Wallace and Mansell 1976).

Todd et al. (1971), working with the greenbug, S. graminum, observed that several phenolic compounds were detrimental to the growth and fecundity of this common pest on barley (Hordeum vulgare L.). Catechol, a phenolic benzene derivative, successfully reduced average weight of greenbugs when incorporated in a synthetic diet at a $3.75 \times 10^{-4} \mathrm{M}$ concentration. This compound also completely eliminated all live progeny of the adult. Salicylic, phydroxybenzoic, gentisic, protocatechuric, vanillic and syringic acids all reduced the number of live progeny over the control groups. Total progeny of greenbugs was drastically reduced as compared to the control when gentisic, protocatechuric, and syringic acids were incorporated in the diet at a $3.75 \times 10^{-4} \mathrm{M}$ concentration. Cinnamic acid derivatives also yielded deleterious responses to the greenbug as did the flavonol quercetin. Todd et al. (1971) noted that many of the compounds that were toxic to the greenbug were present in resistant barley strains. This suggests that some of the inherent host-plant resistance in barley may be the plant's ability to synthesize certain phenolic compounds. Phenolic acids are of small molecular weight and are somewhat soluble in many solvents including water. These characteristics are vital properties of plant toxin since they must pass through cell membranes to be readily available (Rhoades and Cates 1979). Todd et al. (1971) found many phenolic acids present in higher plants to be toxic to the greenbug, suggesting that they may be instrumental in hostplant resistance to insects.

Observations suggest that insects prefer grasses on the basis of nutritional content (Asay et al. 1975, 1983; Haws et al. 1978, 1982; Ling et al. 1982a, b). Whether that preference or nonpreference can be attributed to palatability, induced by such grass components as structural or nonstructural carbohydrates, proteins, phospholipids, flavonoids, certain amino acids, or certain phenolic compounds, is unknown. The literature revealed no direct correlations of nutritional analyses of range grasses with insect preference or nonpreference. Recently, however, high positive correlations have been reported between grass bug damage and chemical constituents, $\mathrm{C}_{5} \mathrm{H}_{7}$ and $\mathrm{C}_{5} \mathrm{H}_{8}$, in certain wheatgrasses but not in orchardgrass and reed canarygrass (Ling et al. 1982a). McKendrick and Bleicher (1980), working with [Irbisia sericans (Stal)] (Hemiptera:Miridae) on bluejoint reedgrass (Calamagrostis candensis L.), noted that percentages of crude protein, $\mathrm{Mg}, \mathrm{Ca}$, and hemicellulose were positively correlated with percentages of damaged leaf area and that total nonstructural carbohydrates (TNC) was negatively correlated with leaf damage. Data collected by Windig et al. (1983), who used pyrolysis-mass spectrometry (Py-MS) in combination with multivariate statistical analysis, did, however, indicate a possible role of phospholipids, proteins, isopronoids, and glycosides with phenolic aglycols in the feeding behavior of $L$. hesperius on range grasses.

Although it has not been substantiated in grass cultivars, resistance may control or suppress insect damage without reducing the nutritive quality. Kehr et al. (1968) and Kindler et al. (1971) recorded similar protein, carotene, and digestible dry matter contents in alfalfa (Medicago sativa $\mathrm{L}$.) cultivars that were susceptible or resistant to the pea aphid [Acyrthosiphon pisum (Harris)] and spotted alfalfa aphid, [Therioaphis maculata (Buckton)] (Homoptera:Aphididae). Barnes et al. (1970) reported that neither digestibility coefficients nor performance of yearling Holsteins differed significantly when fed resistant or susceptible alfalfa cultivars. Potentially, quality and nutritive values can be improved by host plant resistance because less protein, carotene, and vitamins would be lost from resistant than from susceptible grass cultivars. Protein yields of resistant 'Kanza' alfalfa attacked by the pea aphid were almost double and its carotene yields triple those of the susceptible cultivars 'Buffalo', 'Ranger', and 'Vernal' (Sorensen et al., 1969a, b). By contrast, Loper (1968) reported a higher coumestrol content accumulated in aphid-susceptible 'Vernal' than in resistant 'Moapa' and 'Washoe' cultivars when all were subjected to aphids. Selection in alfalfa for aphid resistance can be expected to reduce the accumulation of coumestrol that results from aphid damage.

Feeding preferences between insects and livestock may be similar for the same grass lines. Survival and growth rates of crickets on diets of various forages have been positively correlated with comparable data from large animals in trials conducted in Missouri (Pfander et al. 1964, Stone and Matches 1966). In subsequent trials, crickets were used to detect differences in the forage quality of tall fescue (Festuca arundinacea Schreb.) plants. Significant differences in cricket survival and growth rates were associated with the genetically different grasses (Asay et al. 1975). Hence, care must be taken to prevent resistant characters in improved range grasses from interfering with livestock palatability. It is imperative that insect resistant cultivars be field tested by livestock. However, since insect resistance has been successfully selected for other forage crops, it is reasonable to expect the development of grass cultivars that will fulfill all forage requirements.

\section{Conclusions}

Development of insect resistant cultivars represents a virtually untapped means of reducing the damaging effects of insects on range grasses. Considering the obvious economic and environmental advantages, it would appear that research could well be expanded to realize these benefits. Evidently sufficient genetic variation is present in breeding populations of important range grasses to effectively select for resistance to the black grass bug. However, we have only fragmentary information available regarding the mechanisms in the plant that condition insect feeding behavior. Until these morphological and biochemical factors are better understood, screening and selection for resistance must be based on actual plant responses to the attacking insect. The ultimate objective will be to genetically alter those plant characteristics responsible for resistance, thereby maximizing the production of western rangelands to meet expanding demands imposed by future needs.

\section{Literature Cited}

Adkisson, P.L., and V.A. Dyck. 1980. Resistant varieties in pest management systems. p. 233-251. In: F.G. Maxell and P.R. Jennings, (Eds.). Breeding Plants Resistant to Insects. John Wiley and Sons, NY.

Asay, K.H., T.R. Minnick, G.B. Garner, and B.W. Harmon. 1975. Use of crickets in a bioassay of forage quality in tall fescue. Crop Sci. 15:585-588. 
Asay, K.H., J.D. Hansen, B.A. Haws, and P.O. Currie. 1983. Genetic differences in resistance of range grasses to a grass billbug, Sphenophorus parvulus (Coleoptera:Curculionidae). J. Range Manage. 36:771-772.

Baker, P.B., R.H. Ratcliffe, and A.L. Steinhawer, 1981. Tolerance to hairy chinch bug feeding in Kentucky bluegrass. Envrion. Entomol. 10:153-157.

Barnes, D.K., C.H. Hanson, R.H. Ratcliffe, T.H. Buabice, J.A. Schillinger, G.R. Buss, W.V. Campbell, R.W. Hemken, and C.C. Blickenstaff. 1970. The development and performance of Team alfalfa, a multiple pest resistant alfalfa with modern resistance to the alfalfa weevil. USDA ARS 34-115.

Beck, S.D. 1965. Resistance of plants to insects. Annu. Rev. Entomol. 10:207-232.

Beck, S.D., and F.G. Maxwell. 1976. Use of plant resistance. p. 615-631. In: C.B. Huffaker and P.S. Messenger (Eds.). Theory and practice of biological control. Academic Press. N.Y.

Beck, S.D., and J.C. Reese. 1976. Insect plant interactions: Nutrition and metabolism. Rec. Adv. Phytochem. 10:41-92.

Benson, W.S., K.S. Brown, Jr., and L.E. Gilbert. 1975. Coevolution of plants and herbivores: Passion flower butterflies. Evolution 29:659-680.

Bohning, J.W., and W.F. Currier. 1967. Does your range have wheatgrass grass bugs. J. Range Manage. 20:265-267.

Brewer, P.S., and W.F. Campbell. 1977. Anatomical studies of Labops hesperius damage to crested wheatgrass leaves. Agron. Abstr. p. 50.

Brewer, P.S., W.F. Campbell, and B.A. Haws. 1979. How black grass bugs operate. Utah Sci. 40:21-23.

Chapman, R.F.1974. The chemical inhibition of feeding by phytophagous insects: A review. Bull. Entomol. Res. 64:339-363.

Cutter, E.G. 1976. Aspects of the structure and development of the aerial surfaces of higher plants. p. 1-40. In: C.H. Dickinson and T.F. Preece (Eds.). Microbiology of Aerial Plant Surfaces. Academic Press, N.Y.

Denning, D.G. 1948. The crested wheatgrass bug. Wyoming Agr. Exp. Sta. Circ. No. 33.

Dewey, D.R. 1983a. New nomenclatural combinations in the North American perennial Triticeae (Gramineae). Brittonia 35:30-33.

Dewey, D.R. 1983b. Historical and current taxonomic perspectives of Agropyron, Elymus, and related genera. Crop Sci. 23:637-642.

Dewey, D.R., and K.H. Asay. 1975. The crested wheatgrasses of Iran. Crop Sci. 15:844-849.

Dickerson, G.W. 1978. Control of black grass bugs (Labops hesperius Uhler) in northern New Mexico. J. Range Manage. 31:398-399.

Ehrlich, P.R., and P.H. Raven. 1964. Butterflies and plants: A study in coevolution. Evolution 18:586-608.

Farrell, J.A.K. 1977. Plant resistance to insects and the selection of resistant lines. N.Z. Entomol. 6:244-261.

Fraenkel, G.S. 1959. The raison d'etre of secondary plant substances. Science 129:1466-1470.

Fraenkel, G.S. 1969. Evaluation of our thoughts on secondary plant substances. Entomol. Exp. Appl. 12:473-486.

Gallun, R.L. 1972. Genetic interrelationships between host plants and insects. J. Environ. Qual. 1:259-265.

Gallun, R.L., and G.S. Khush. 1980. Genetic factors affecting expression and stability of resistance. p. 63-85 In: F.G. Maxwell and R.J. Jennings (Eds.). Breeding Plants Resistant to Insects. John Wiley and Sons, N.Y.

Gallun, R.L., K.J. Starks, and W.D. Guthrie. 1975. Plant resistance to insects attacking cereals. Annu. Rev. Entomol. 20:337-357.

Gallun, R.L., J.J. Roberts, R.E. Finney, and F.L. Patterson. 1973. Leaf pubescence of field grown wheat: A deterrent to oviposition by the cereal leaf beetle. J. Environ. Qual. 2:333-334.

Gilbert, L.E., and P.H. Raven (Eds.). 1975. Coevolution of Animals and Plants. Univ. Texas Press, Austin.

Hagen, K.S., R. van den Bosch, and D.L. Dahlsten. 1971. The importance of naturally-occurring biological control in western United States. p. 253-293. In: C.B. Huffaker (Ed.). Biological Control. Plenum Press, N.Y.

Harborne, J.B. 1982. Introduction to ecological biochemistry. 2nd Ed. Academic Press. N.Y.

Haws, B.A., W.C. Brindley, W.F. Campbell, T.F. Glover, J.C. Malechek, C.M. MeKell, G.W. Miller, R.W. Miller, E.A. Richardson, D.J. Schimpf, and H.H. Wiebe. 1978. Economic impacts of Labops hesperius on the production of high quality range grasses. Utah Agr. Exp. Sta. Rep. to Four Corners Regional Commission.

Haws, B.A., W.F. Campbell, J.O. Evans, T.F. Glover, B.E. Norton, E.A. Richardson, J.R. Werner, D.B. Thomas, J.L. Capinera, R.W. Lauderdale, J.B. Knight, E.W. Huddleston, and W. Smith. 1982. An introduction to beneficial and injurious rangeland insects of the western United States. Utah Agr. Exp. Sta. Special Report 23. ayes, W.P., and C.O. Johnston. 1925. The reaction of certain grasses to chinch-bug attack. J. Agr. Res. 31:575-583.

Hedin, P.A., F.G. Maxwell, and J.N. Jenkins. 1974. Insect plant attractants, feeding stimulants, repellents, deterrents, and other related factors affecting insect behavior. p. 494-527. In: F.G. Maxwell and F.A. Harris (Eds.). Proc. Summer Institute on Biological Control of Plant Insects and Diseases. Univ. Press, Jackson, Miss.

Hedin, P.A. (Ed.). 1983. Plant resistance to insects. CAS Symposium Series No. 208. Amer. Chemical Soc. Washington, D.C. 20036.

Hewitt, G.B. 1980. Tolerance of ten species of Agropyron to feeding by Labops hesperius. J. Econ. Entom. 73:779-782.

Hizgins, K.M., J.E. Bowns, and B.A. Haws. 1977. The black grass bug (Labops hesperius Uhler): Its effect on several native and introduced grasses. J. Range Manage. 30:380-384.

Horber, E. 1972. Plant resistance to insects. Agr. Sci. Rev. Coop. State Res. Ser. USDA. 10:1-10.

Jackson, D.W., K.J. Vessels, and D. A. Potter. 1981. Kentucky research reveals greenbug turfgrass preferences. Weeds, Trees and Turf 20:55-56.

Jensen, F. 1971. Reseeding and Labops. Range Improvement Notes. U.S. Forest Serv. Intermt. Reg. Ogden, Utah. 16:7-9.

Jermy, T. (Ed.). 1976. The host-plant in relation to insect behavior and reproduction. Plenum Press. N.Y.

Kehr, W.R., G.R. Manglitz, and R.L. Ogden. 1968. Dawson alfalfa-a new variety resistant to aphids and bacterial wilt. Neb. Agr. Exp. Sta. Bull. 497.

Kieckhefer, R.W., and W.N. Stoner. 1978. Preferences of four cereal aphids for certain range grasses. Environ. Entomol. 7:617-618.

Kindler, S.D., and E.J. Kinbacher. 1975. Differential reaction of Kentucky bluegrass cultivars to the bluegrass billbug, Sphenophorus parvulus Gyllenhal. Crop Sci. 15:873-874.

Kindler, S.D., W.R. Kehr, and R.L. Ogden. 1971. Influence of pea aphids and spotted alfalfa aphids on the stand, yield of dry matter and chemical composition of resistant and susceptible varieties of alfalfa. J. Econ. Entomol. 64:653-657.

Knowlton, G.F. 1945. Labops damage to range grasses. J. Econ. Entomol. 38:707-708.

Knowlton, G.F. 1967. Grassbugs: A serious range problem in 1966. Utah Acad. Sci. Arts Lett. 43:20-21.

Kogan, J. 1978. The role of chemical factors in insect-plant relationships. Illinois State Natural History Survey. R462:211-227.

Leuck, D.B. 1972. Induced fall armyworm resistance in pearl millet. J. Econ. Entomol. 65:1608-1611.

Levin, D.A. 1973. The role of trichomes in plant defense. The Quart. Rev. Biol. 48:3-15.

Lindgren, D.T., R.C. Shearman, A.H. Bruneau, and D.M. Schar. 1981. Kentucky bluegrass cultivar response to bluegrass billbug, Sphenophorus parvulus Gyllenhal. HortScience 16:339.

Ling, Y.-H., W.F. Campbell, B.A. Haws, and K.H. Asay. 1982a. Identification of range grasses resistant to Labops hesperius. 35th Annu. Meet. Soc. Range Manage. Calgary, Alberta, Canada. Feb. 7-12, 1982.

Ling, Y.-H., W.F. Campbell, B.A. Haws, and K.H. Asay. 1982b. SEM studies of range grass leaf morphology and feeding behavior of black grass bugs. ASA-CSSA-SSSA Annu. Meet. Nov. 28 - Dec. 3, 1982. Anaheim, Calif.

Loper, G.M. 1968. Effect of aphid infestation on the coumestrol content of alfalfa varieties differing in aphid resistance. Crop Sci. 8:104-106.

Maxwell, F.G., and P.R. Jennings (Eds.). 1980. Breeding Plants Resistant to Insects. John Wiley and Sons, N.Y.

Maxwell, F.G., J.N. Jenkins, and W.L. Parrot. 1972. Resistance of plants to insects. Adv. Agron. 24:187-265.

McColloch, J.W., and H. Yuasa. 1917. Notes on the migration of the Hessian fly larvae. J. Anim. Behav. 17:307-323.

McKendrick, J.D., and D.P. Bleicher. 1980. Observations of a grass bug on bluejoint ranges. Agroborealis. 12:15-18.

Mills, H.B. 1939. Montana insect pests for 1937 and 1938. Montana Agr. Exp. Sta. Bull. 366:1-32.

Mittler, T.E., and O.R.W. Sutherland. 1969. Dietary influences on aphid polymorphism. Entomol. Exp. Appl. 12:703-713

Mulkern, G.B., K.P. Pruess, H. Knutson, A.F. Hagen, J.B. Campbell, and J.D. Lambley. 1969. Food habits and preferences of grassland and grasshoppers of the North Central Great Plains. North Dakota State Univ. Agr. Exp. Sta. Bull. 481:1-32.

Norris, D.M., and M. Kogan. 1980. Biochemical and morphological bases of resistance. p. 23-62. In: F.G. Maxwell and P.R. Jennings (Eds.). Breeding Plants Resistant to Insects. John Wiley and Sons. N.Y. 
Ortman, E.E., and D.C. Peters. 1980. Introduction. p. 3-13. In: F.G. Maxwell and P.R. Jennings (Eds.). Breeding Plants Resistant to Insects. John Wiley and Sons. N.Y.

Painter, R.H. 1951. Insect resistance in crop plants. The MacMillan Co., N.Y.

Painter, R.H. 1958. Resistance of plants to insects. Annu. Rev. Entomol. 3:267-290.

Pfander, W.H., W.A. Hargus, W. Tyree, and P.C. Stone. 1964. The use of crickets to evaluate ruminant rations. Amer. Soc. Exp. Biol. 23. Part 1.

Reinert, J.A., and A.E. Dudeck. 1974. Southern chinch bug resistance in St. Augustinegrass. J. Econ. Entomol. 67:275-277.

Rhoades, D.F., and R.G. Cates. 1979. Biochemical interaction between plants and insects toward a general theory of plant antiherbivore chemistry. Chapter 4. In: J.W. Wallace and R.L. Mansell (Eds.). Rec. Adv. Phytochem. 10:168-213.

Rogler, G.A., and R.J. Lorenz. 1983. Crested wheatgrass-carly history in the United States. J. Range Manage. 36:91-93.

Rosenthal, G.A., and D.H. Janzen (Eds.). 1979. Herbivores: Their interaction with secondary plant metabolites. Academic Press. N.Y.

Russell, G.E. 1978. Plant breeding for pest and disease resistance. Butterworths. London and Boston.

Ryan, C.A. 173. Proteolytic enzymes and their inhibitors in plants. Annu. Rev. Pl. Physiol. 24:173-196.

Ryan, C.A., and T.R. Green. 1974. Proteinase inhibitors in natural plant protection. Rec. Adv. Phytochem. 8:123-140.

Schoonhoven, L.M. 1972. Secondary plant substances and insects. Rec. Adv. Phytochem. 4:197-224.

Schoonhoven, L.M., and Derksen-Koppers. 1976. Effect of some allelochemics on food uptake and survival of polyphagous aphid, Myzus persicae. Entomol. Exp. Appl. 19:52-56.

Slama, K. 1969. Plants as a source of materials with insect hormone activity. Entomol. Exp. Appl. 12:721-728.

Slater, J.A. 1954. Notes on the genus Labops, Burmeister in North America, with the descriptions of three new species (Hemiptera:Miridae). Bull. Brooklyn Entomol. Soc. 49:57-65.

Sorensen, E.L., T.L. Harvey, and H.L. Hackerott. 1969a. New alfalfa unappetizing to pea aphid. Crops and Soils. 22:22.

Sorensen, E.L., R.H. Painter, H.L. Hackerott, and T.L. Harvey. 1969b. Registration of Kanza alfalfa. Crop Sci. 9:847.

Stone, P.C., and A.G. Matches. 1966. Cricket growth and survival on forage diets. Entomol. Soc. Amer. Proc. N. Cent. 21:133-135.
Stoner, W.N., and R.W. Kicekhefer. 1979. Survival and reproduction of four cereal aphids on certain ranges grasses. Environ. Entomol. 8:694-695.

Swain, T. 1977. Secondary compounds as protective agents. Ann. Rev. PI. Physiol. 28:479-501.

Thurston, R. 1970. Toxicity of trichome exudates of Nicotiana and Petunia species to tobacco hornworm larvae. J. Econ. Entomol. 63:272-274.

Thurston, R., W.T. Smith, and B.P. Cooper. 1966. Alkaloid secretion by trichomes of Nicotiana species and resistance to aphids. Entomol. Exp. Appl 9:428-432.

Tingey, W.M., J.D. MacKenzie, and P. Gregory. 1978. Total foliar glycoalkaloids and resistance of wild potato species to Empoasca fabae (Harris). Amer. Potato J. 55:577-585.

Todd, J.G., and J.A. Kamm. 1974. Biology and impact of a grass bug, Labops hesperius Uhler, In Oregon rangeland. J. Range Manage. 27:453-458.

Todd, G.W., A. Getahun, and R.C. Cross. 1971. Resistance in barley to the greenbug, Schizaphis graminum. Toxicity of phenolic and flavonoid compounds and related substances. Ann. Entomol. Soc. Amer. 64:718722.

Uphof, J.D. Th. 1962. Plant hairs. p. 1-206. In: W. Zimmermann and P.C. Ozenda (Eds.). Encyclopedia of Plant Anatomy. Vol. 4, Part 4. Gebruder Borntraeger. Berlin.

Waiss, A.C., Jr., B.G. Chan, and C.A. Elliger. 1977. Host plant resistance to insects. p. 115-128. In: P.A. Hedin (Ed.). Host Plant Resistance to Pests. Amer. Chem. Soc., Washington, D.C.

Wallace, J.W., and R.L. Mansell (Eds.). 1976. Biochemical interactions between plants and insects. Plenum Press, N.Y.

Watts, J.G. 1965. Chirothrips falsus on black grama grass. New Mexico State Univ. Agr. Sta. Bull. 499:1-20.

White, T.C.R. 1976. Weather, food and plagues of locusts. Oecologia. 22:119-134.

Wilson, R.L., K.J. Starks, H. Pass, and E.A. Wood. 1978. Resistance in four oat lines to two biotypes of the greenbug. J. Econ. Entomol. 71:886-887.

Windig, W., H.L.C. Meuxelaar, B.A. Haws, W.F. Campbell, and K.H. Asay. 1983. Biochemical differences observed in pyrolysis mass spectra of range grasses with different resistance to Labops hesperius Uhler attack. J. Anal. \& Appl. Pyrolysis. 5:183-198. 